Bolm Inst. oceanogr., S Paulo, 32(1):91-98, 1983

\title{
NOTE ON THE EFFECT OF HIGH NITRATE CONCENTRATION AND LIGHT INTENSITY ON THE GROWTH AND UPTAKE RATES OF PHAEODACTYLUM TRICORNUTUM (BOHLIN) CULTURE
}

\author{
Gilda SCHMIDT
}

Instituto Oceanogräfico da Universidade de São Paulo

\begin{abstract}
Synopsis
The effect of high nitrate concentration and light intensity on chlorophyll-a synthesis, cell number and nitrate assimilation on P. tricornutum culture, was determined. Growth and uptake rates were determined as a function of nitrate concentration ranging from 0.40 to $35.40 \mathrm{\mu g} / \mathrm{l}$. The $\mathrm{Ks}$ showed high values, when compared with those obtained with lower nitrate concentration. The percentual variation of Ks was greater than that of Vmax.

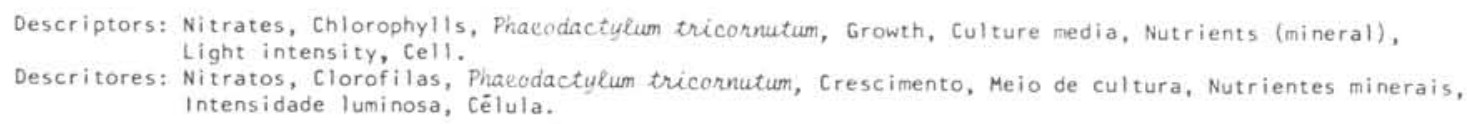

\section{Introduction}

The growth and uptake rates of marine phytoplankton are known to be under the influence of nitrogenous nutrients, light intensity and temperature Teixeira \& Vieira (1976) showed that $P$. tricornutum growth could be limited by low nitrogenous nutrient concentration. Morris et al. (1974) related that P. tricornutum increases photosynthesis rate with decreasing light intensity, higher at 0.5 KLUX than at 9 KLUX. The constants Ks and Vmax are important ecological parameters (MacIsaac \& Dugdale, 1969; Thomas \& Dodson, 1974). The purpose of this work was to test the influence of high nitrate concentration and light intensity on these two parameters on $P$. tricornutum culture.

\section{Material and methods}

The clone of $P$. tricornutum was isolated from Ubatuba (SP) region and maintained in medium " $f$ " (Guillard \& Ryther, 1962), non-axenic culture, 3 KLUX intensity given by fluorescent day-light type lamps, continuous regime, in a BOD type incubator, at $22{ }^{\circ} \mathrm{C}$ temperature. The culture medium for the experiment was prepared with surface water from the same region. Table 1 shows hydrographic parameters and initial cell number, chlorophyl1- $a$ and nitrate concentration. Depleted nitrate cells were grown in Erlenmeyers flasks containing medium " $f$ " Publ. n. 588 do Inst. oceanogr. da Usp. without nitrogenous nutrient, until they reached the stationary phase. Then the organisms in a concentration of $6.9 \mathrm{x}$ $10^{4} \mathrm{ml}$ were put in a series of 7 Erlenmeyers flasks of $300 \mathrm{ml}$ capacity, containing $200 \mathrm{ml}$ of medium " $f$ " to which crescent nitrate amounts were added, from 0.00 to $35.00 \mu \mathrm{g}-\mathrm{at} / 1$. The flasks were transferred to a BOD type incubator, $22 \pm 0.5^{\circ} \mathrm{C}$ and 12 KLUX light intensity, given by 6 fluorescent day-light lamps, $20 \mathrm{~W}$ each, continuous regime. Sampling was done every 24 hours, until the 5 th day of the experiment. The active chlorophyl1- $a$ was determined according to Strickland \& Parsons (1968). The cell number was counted with a FucksRosenthal chamber. Nitrate concentration was determined according to Mullin \& Riley (1955)'s hydrazine sulphate reduction technique, as described by Strickland \& Parsons (op. cit.). The growth and uptake rates and the constants Ks and Vmax were calculated according to Thomas (1970). The slope of the straight line on the semilogarithmic paper (Fig. 1a,b,c) was utilized to calculate the generation time $(\theta)$, that is, the time required for the population of $P$. tricornutum to double as cell number, synthesized chlorophy11- $a$ and assimilated nitrate, according to Fairchild \& Sheridan (1974).

\section{Results}

Figure 1 shows: $a$ - The cell number; $b$ synthesized chlorophy11- $a$ and $c$ - nitrate 
92

Balm Inst. oceanogr., S Paula, 32(1), 1983

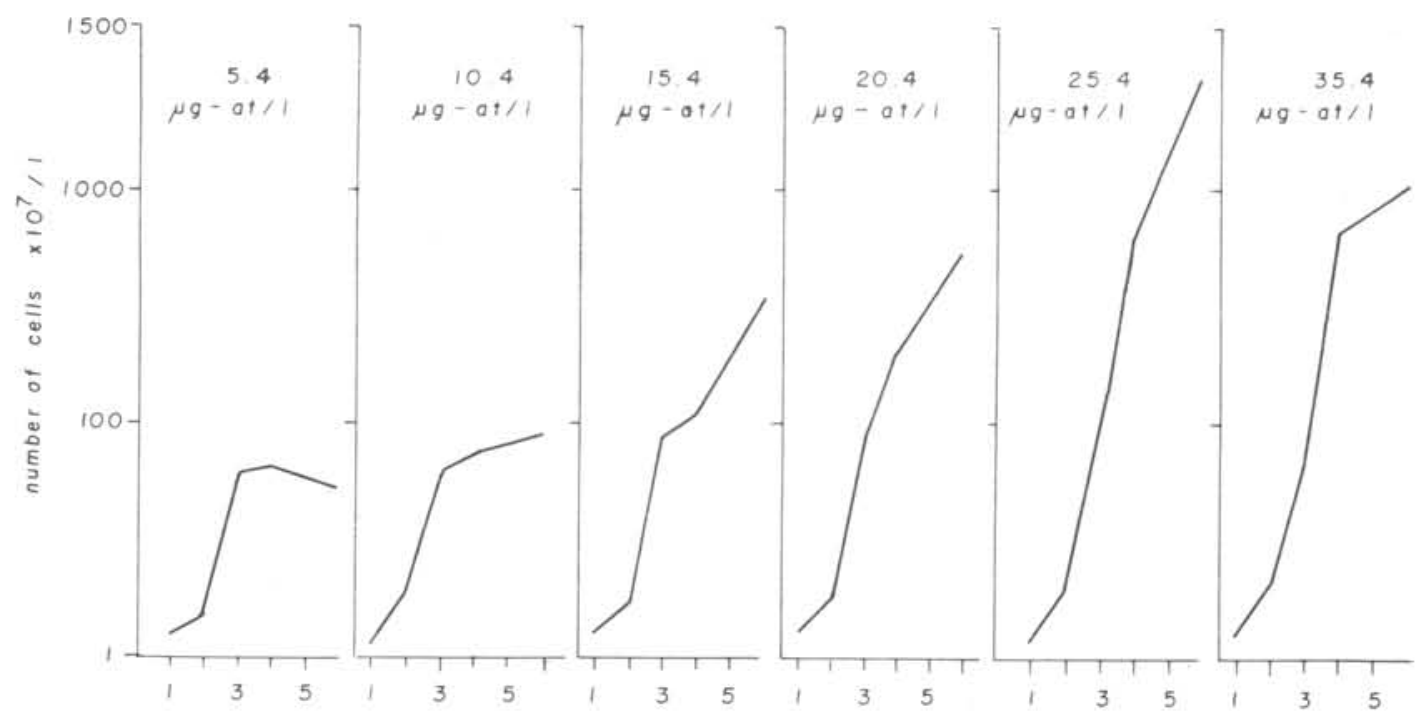

a

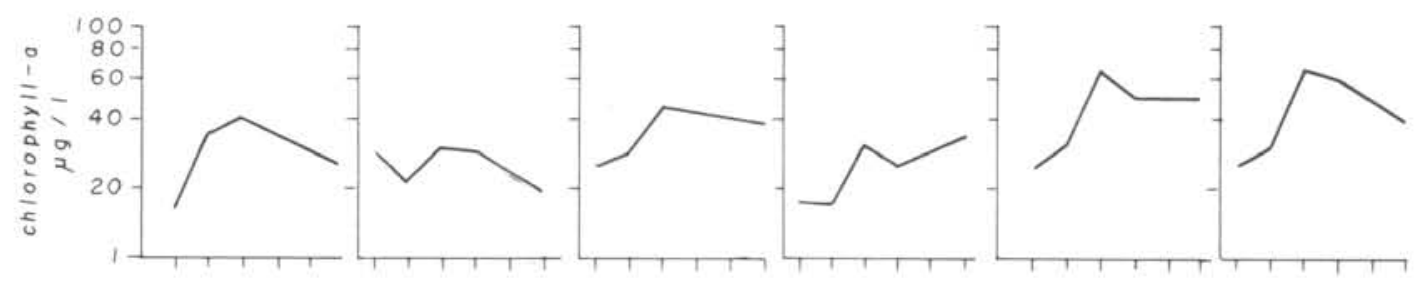

b

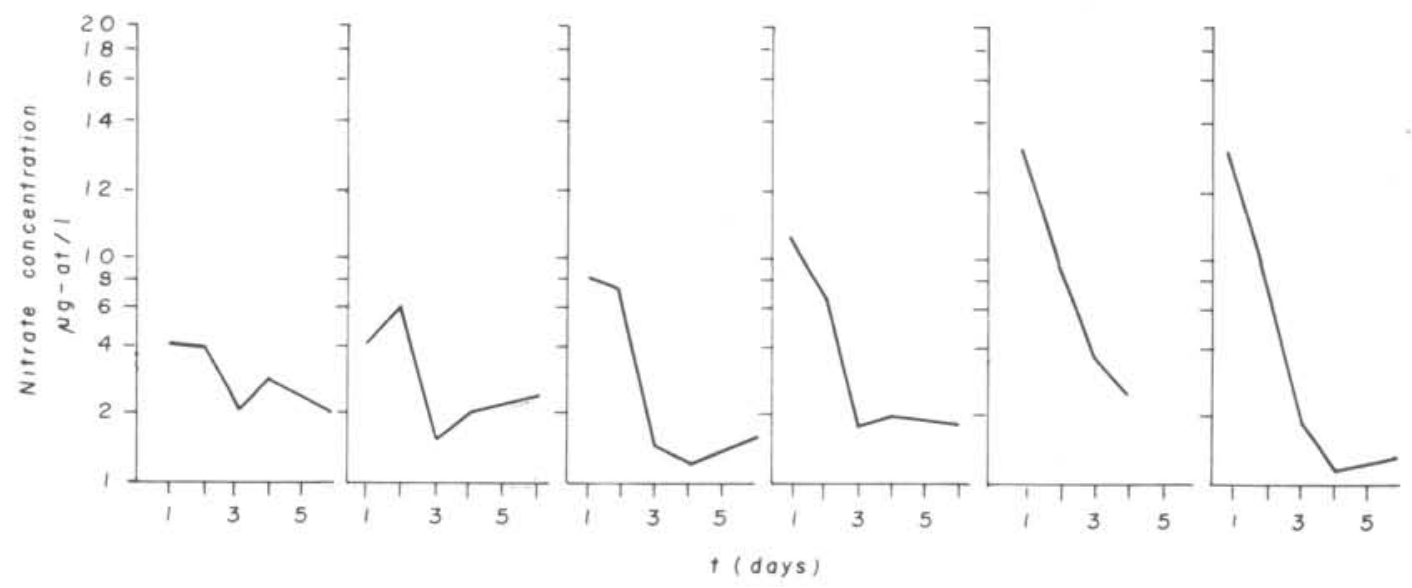

c

Fig. 1. a) Cell number; b) synthesized chlorophyll-a, and c) nitrate concentration of the culture medium, as a function of time, for each nitrate concentration; the initial nitrate concentration is shown at the top. 
concentration in the $P$. tricornutum culture medium, plotted in the abscissa and time in the ordinate for each nitrate concentration. The plotting of the cell number appeared as an almost perfect straight line, while synthesized chlorophyl1- $a$ and nitrate uptake lines increased and decreased with time. These variations will be commented later. The initial nitrate concentratior in culture medium, generation time $(\theta)$, growth and uptake rate, $\mu$, are listed in Table 2. Nul1 hypothesis between growth rate estimated as synthesized chlorophyl1-a and cell number medium values, that is, Ho: $\mu_{1}=u_{2}$, was $t=-0.73$, for $N=12$, The medium value differences were random, at 1 and $5 \%$ significance leve1. Figure $2 a$ shows growth rate estimated as $P$. tricornutum culture synthesized chlorophyl1- $a$ in the abscissa and nitrate concentrations in the ordinate. The data did not present a perfect retangular hyperbole. The linear plot of $\mathrm{S} / \mu$ versus $\mathrm{S}$ values is shown in Figure $2 b$, the $\mathrm{Ks}$ is in the negative intercept and Vmax in the slope of the regression equation. Figure 3 shows the growth rate of $P$. tricornutum culture, estimated as cell number in the culture medium, as a function of nitrate concentration. The $S / \mu$ vs $S$ plot shows Ks and Vmax values. The nitrate uptake rate, as a function of the nitrate concentrations, is shown in Figure 4. The linearization plot shows $\mathrm{Ks}$ and Vmax values. Table 3 shows the Ks and Vmax values with $95 \%$ confidence interval. Ks and Vmax were estimated from growth and uptake rate values (Table 2). Ks and Vmax obtained with the synthesized chlorophy11- $a$ values, $18.22 \mu \mathrm{M}$ and 1.57 doublings/day, respectively, indicated that chlorophyll-a synthesis seemed to be the most sensible variable to the experimental conditions. Growth rate Ks and Vmax estimated as cell number were $3.14 \mu \mathrm{M}$ and 1.71 doublings/day, and

Table 1. Hydrographic parameters, seawater nitrate, Initial chlorophyll-a and cell number

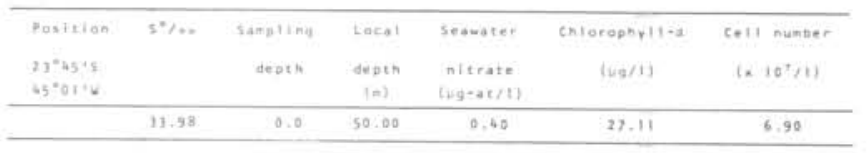

Table 2. Nitrate concentrations, generation time, $\theta$, growth and uptake rates, $u$, estimated as cell number, synthesized chlorophyll- $a$ and assimilated nitrate in $P$. tricornutum culture

\begin{tabular}{|c|c|c|c|}
\hline & $\begin{array}{c}\mathrm{N}-\mathrm{NO}_{3} \\
\mu \mathrm{g}-\mathrm{at} / \mathrm{I}\end{array}$ & $\begin{array}{c}\text { Generation } \\
\text { time(days) } \\
\theta\end{array}$ & $\begin{array}{c}\text { Growth rate } \\
\mu=\frac{0.693}{\theta} \\
\text { (doublings/day) }\end{array}$ \\
\hline \multirow{4}{*}{$\begin{array}{l}\text { ¿ } \\
\stackrel{0}{\circ} \\
\text { E } \\
\text { c }\end{array}$} & 0.4 & 2.55 & 0.27 \\
\hline & 5.4 & 0.77 & 0.90 \\
\hline & 10.4 & 0.60 & 1.16 \\
\hline & 15.4 & 0.43 & 1.61 \\
\hline \multirow{3}{*}{$\bar{\Xi}$} & 20.4 & 0.47 & 1.47 \\
\hline & 25.4 & 0.42 & 1.65 \\
\hline & 35.4 & 0.46 & 1.31 \\
\hline \multirow{8}{*}{ 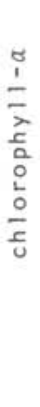 } & 0.4 & 1.91 & 0.36 \\
\hline & 5.4 & 2.05 & 0.34 \\
\hline & 10.4 & 1.51 & 0.46 \\
\hline & 15.4 & 1.30 & 0.53 \\
\hline & 20.4 & 1.10 & 0.63 \\
\hline & 25.4 & 0.60 & 1.15 \\
\hline & 35.4 & 0.55 & 1.26 \\
\hline & & & $\begin{array}{l}\text { Uptake rate } \\
\mu=\frac{0.693}{\theta}\end{array}$ \\
\hline \multirow{7}{*}{ 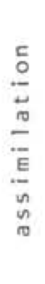 } & 0.4 & 2.10 & 0.33 \\
\hline & 5.4 & 1.10 & 0.63 \\
\hline & 10.4 & 0.50 & 1.38 \\
\hline & 15.4 & 0.40 & 1.73 \\
\hline & 20.4 & 0.30 & 2.31 \\
\hline & 25.4 & 0.35 & 1.98 \\
\hline & 35.4 & 0.31 & 2.23 \\
\hline
\end{tabular}

Table 3. Growth rate $K_{S}$ and $V_{\max }$, with $95 \%$ confidence intervals, estimated as cell number and synthesized chlorophyll-a; uptake rate $\mathrm{K}_{\mathrm{S}}$ and $\mathrm{V}_{\max }$ with $95 \%$ confidence intervals, estimated as nitrate consumed from culture medium

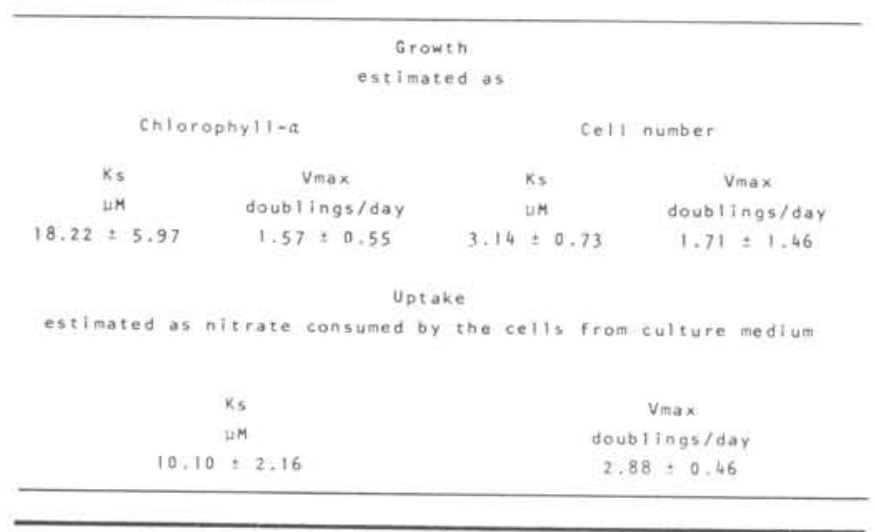


these values are rather in agreement with the expected values for Ks and Vmax for $P$. tricornutum cells growing with nitrate as nitrogen source (MacIsaac \& Dugdale, 1969; Collos \& Slawyk, 1979). The Ks and Vmax for the uptake rate of nitrate were $10.10 \mu \mathrm{M}$ and 2.88 doublings/ day, respectively. The Ks and Vmax values obtained in this work, presented percentual of Ks greater than those of Vmax.

\section{Discussion}

Chlorophy11- $a$ concentrations of $P$. tricornutum culture are shown in Figure 1b. At the 3 rd day of the experiment the chlorophy11- $a$ presented a maximum value, followed by a decrease. Only at the concentration $20.40 \mu \mathrm{g} / \mathrm{at} / 1 \mathrm{~N}-\mathrm{NO}_{3}$, the chlorophy11-a increased, on the 5th day. According to Sournia (1974) and Meeks (1974) light is the main influence on the cellular chlorophyll concentration and high light intensity could inhibit synthesis and promote pigment bleaching. The relatively low chlorophyl1-a content of $P$. tricornutum culture showed in Figure $1 b$ and, consequent1y, the low growth rates (Table 2) could, probably, be explained by the high light intensity (12 KLUX) used in the experiment. The cells had been cultured at 3 KLUX light intensity and, according to Beardall \& Morris (1976), P. tricornutum ce11s growing at 0.7 KLUX presented a decrease in chlorophyl1- $a$ contents when exposed to a 12 KLUX 1 ight intensity source. In this work, the cellular chlorophyll-a concentration values were ten times

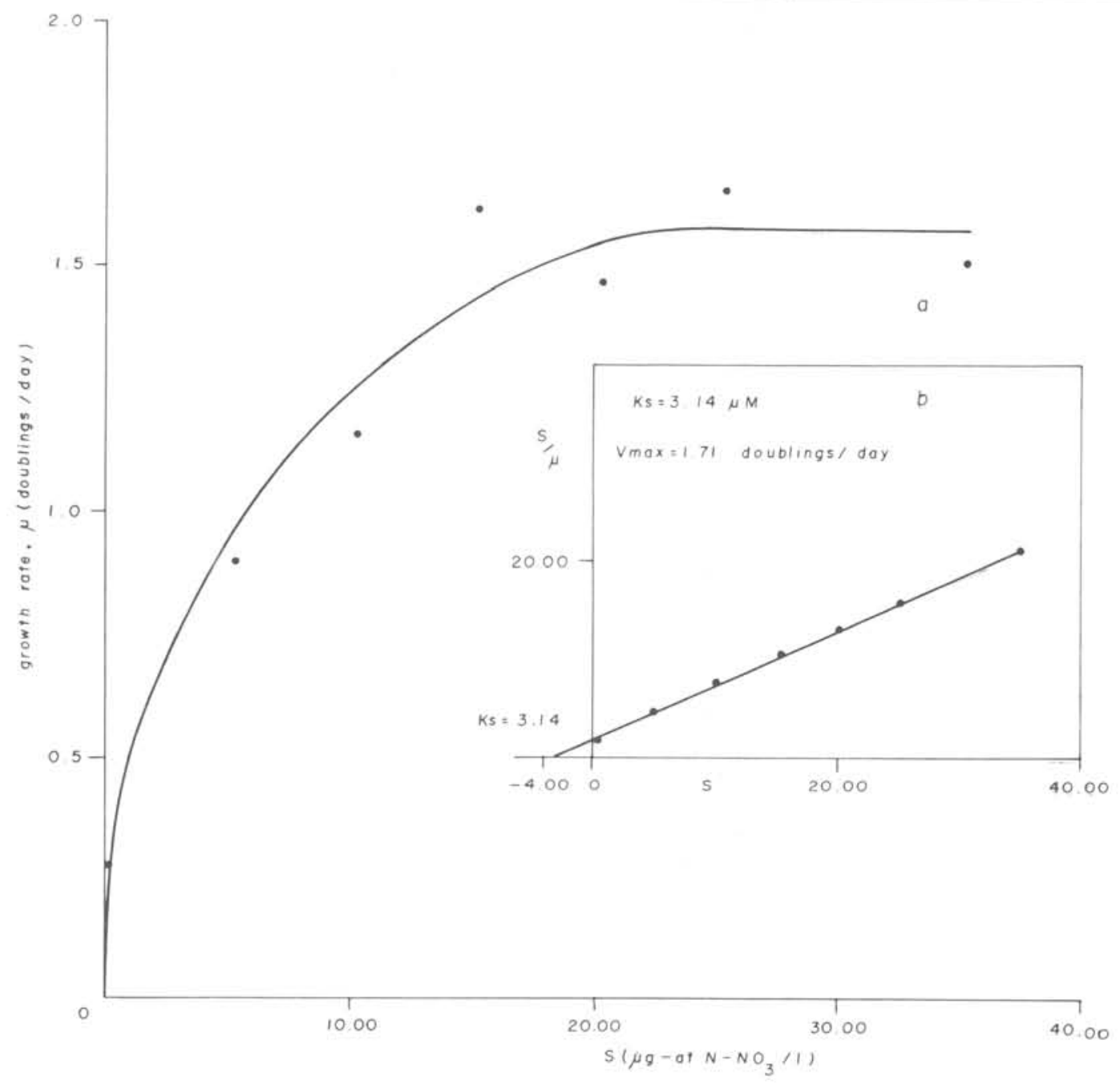

Fig. 2. a) Growth rate of $P$. tricornutum, estimated as cell number, as a function of culture medium nitrate concentration; b) linearization by plotting $S / \mu$ vs $\mathrm{S}$, showing $\mathrm{K}_{\mathrm{S}}$ and $\mathrm{V}_{\max }$. 


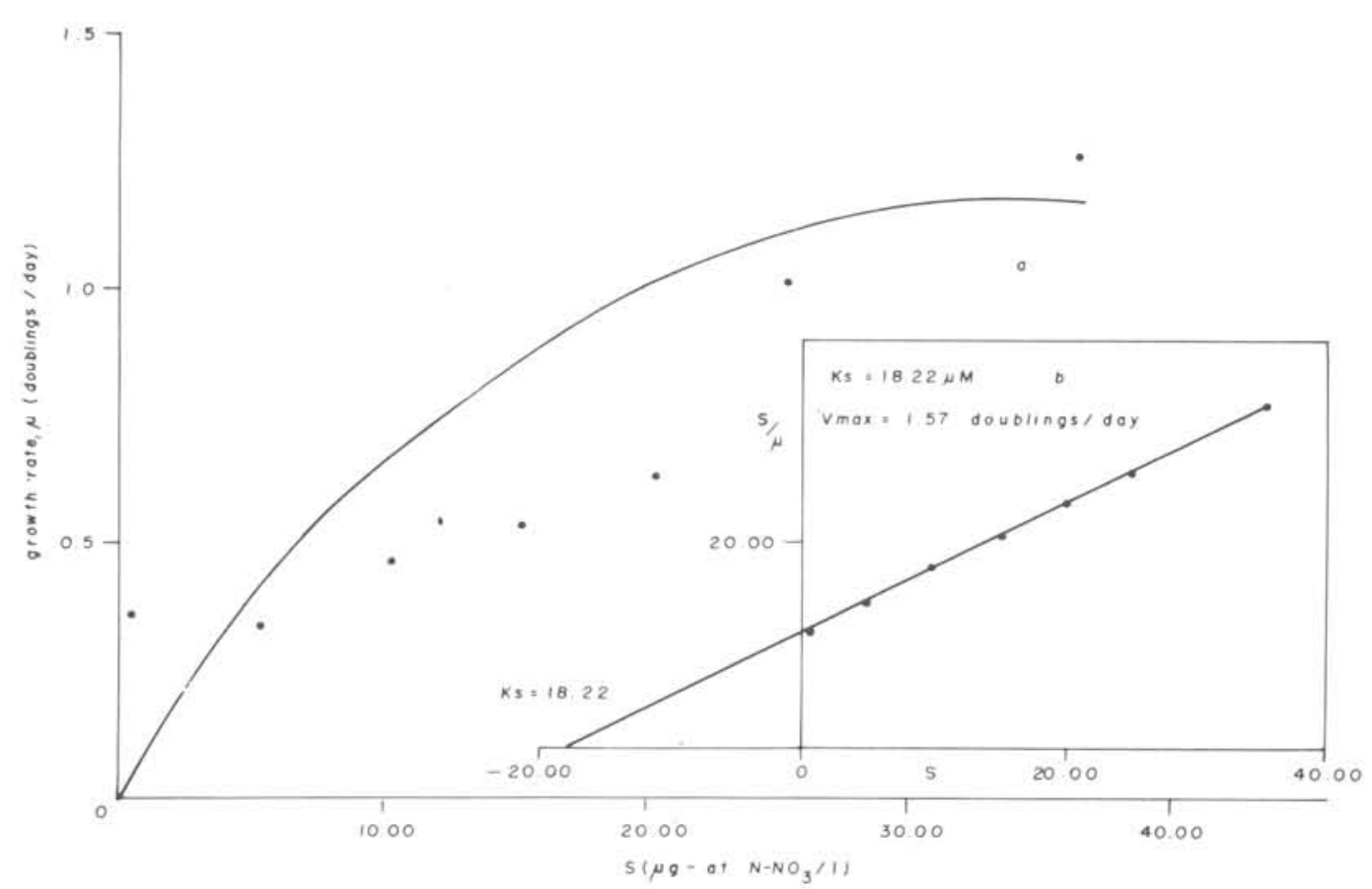

Fig. 3. a) Growth rate of $P$. tricornutum, estimated as chlorophyll-a, as a function of culture medium nitrate concentration; b) linearization by plotting $S / \mu$ vs $S$, showing $K_{S}$ and $V_{\max }$.

lower than those obtained by Beardall \& Morris (op. cit.). The high ks growth rate value, $18.22 \mu \mathrm{M}$, and 1 ow $\operatorname{Vmax} 1.57$ doublings/day (Table 3; Fig. 2) presented by $P$. tricornutum culture could be attributed to the low cellular chlorophyl1-a contents. According to Dugdale (1967) low Ks and high Vmax values are conditions of maximum production. Figure 1c shows the nitrate uptake by $P$. tricornutum during the experiment. Nitrate uptake was considered as the nitrate consumed from the culture medium every day, during the experiment. The concentration increase on the last day can be an irregularity that could be attributed to nitrite releases to the medium by $P$. tricornutum cells (Collos \& Slawyck, 1979; Collos, 1982). Co11os (op. cit.), working with P. tricornutum, reported that nitrite appeared in the medium after a few hours of nitrate addition. The increase of cell number during the experiment is shown in Figure 1a. The cell division rate did not seem to be affected by the 1 ight intensity. Paasche (1968), working with Nitzchia turgidula, related that this diatom did not have the cell division rate affected by 24 KLUX light intensity. The Ks and Vmax for growth rate estimated as cell number values were $3.14 \mu \mathrm{M}$ and 1.57 doublings/day, respectively (Table 3; Fig. 3). MacIsaac \& Dugdale (1969) observed that Ks and Vmax obtained for eutrophic regions, are comparable to those for laboratory cultures. These authors found $4.21 \mu \mathrm{M}$ for $\mathrm{NO}_{3} \mathrm{Ks}$ of an eutrophic region population and $2.83 \mu \mathrm{M}$ for $\mathrm{NO}_{3}$ growth rate of Isochrysis galbana growing in a chemostat culture. The nitrate concentrations utilized in this work (Table 2) can be considered as of nutrient rich water, since Thomas (1970) 1 isted a mean value of $5.6 \mu \mathrm{g}-\mathrm{at} / 1$ $\mathrm{N}-\mathrm{NO}_{3}$ as characterizing an eutrophic seawater region. The Ks for uptake can exceed the Ks for growth rate by one order of magnitude (Eppley \& Thomas, 1969). In this work, the Ks for growth rate estimated as cell number was $3.14 \mu \mathrm{M}$ and the $\mathrm{Ks}$ for nitrate uptake rate was $10.10 \mu \mathrm{M}$. According to Collos (1980) eutrophic wațers have high Ks values and oligotrophic low Ks ones. The Ks and Vmax showed in Table 3 could, perhaps, be compared to those obtained for nutrient rich seawaters. The author of this study, working with the same clone of $P$. tricornutum, found a $\mathrm{NO}_{3} \mathrm{Ks}$ of $0.37 \mu \mathrm{M}$ and Vmax of 2.21 doublings/ day for growth rate estimated as cell 


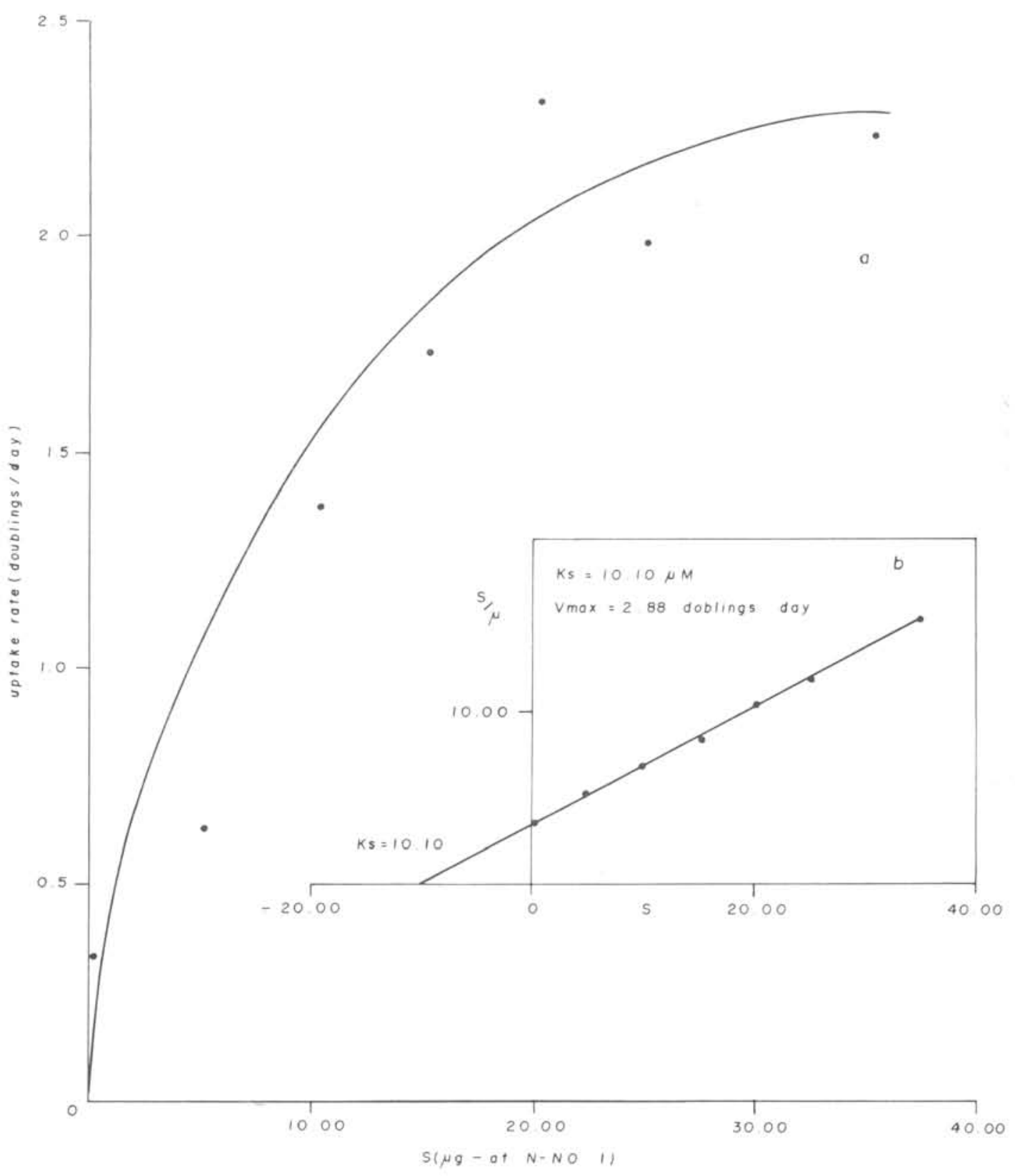

Fig. 4. a) Uptake rate of $P$. tricornutum estimated as nitrate assimilated, as a function of culture medium concentration; b) linearization by plotting $S / \mu$ vs $S$, showing $K_{S}$ and $V_{\max }$.

number, and Ks of $2.30 \mu \mathrm{M}$ and Vmax of 1.07 doublings/day for nitrate uptake rate, nitrate concentrations ranging from 0.90 to $10.00 \mu \mathrm{g}-\mathrm{at} / 1,5 \mathrm{KLUX}$ light. intensity (Schmidt, 1982). The P. tricornutum kinectics values presented here could be explained by: a) instability of chlorophy11-a synthesis (Sournia, 1974); b) physiological stress of cells, due to the large starvation period (Collos, 1980); c) high light intensity, near to the saturation point and self-shading (Vieira, 1975). Other factors would influence these results and new experiments must be carried on so as to confirm or not these data.

\section{Resumo}

Foi determinado o efeito de uma alta concentração de nitrato e alta intensidade luminosa na síntese de clorofila-a, número de células e assimilação de nitrato em uma cultura de P. tricornutum. As velocidades de crescimento e de assimilação foram determinadas em função de 
concentrações de nitrato variando de 0,40 a $35,40 \mu \mathrm{g}-a t / 1$ e intensidade 1 uminosa de $12 \mathrm{kLUX}$. A Ks e a Vmax apresentaram valores altos, comparativamente com valores obtidos em concentrações mais baixas de nitrato e menor intensidade luminosa. A variação porcentual da Ks foi maior que a variação porcentual da Vmax.

\section{References}

BEARDALL, J. \& MORRIS, I. 1976. The concept of 1 igth intensity adaptation in marine phytoplankton: some experiments with Phaeodactylum tricornutum. Mar. Biol., 37:377-387.

COLLOS, Y. 1980. Transient situations in nitrate assimilation by marine diatoms. 1. Changes in uptake parameters during nitrogen starvation. Limno1. Oceanogr., 25(6):1075-1081.

\section{Transient situations}

in nitrate assimilation by marine diatoms. 2. Changes in nitrate and nitrite following a nitrate perturbation. Limnol. Oceanogr., 27(3): 528-535.

\& SLAWYK, G. 1979, ${ }^{13} \mathrm{C}$ and ${ }^{15} \mathrm{~N}$ uptake by marine phytoplankton. I. Influence of nitrogen source and concentration in laboratory culture of diatoms. J. Phycol., 15:186-190.

DUGDALE, E. 1967. Nutrient limitation in the sea: dynamics, identification and significance. Limnol. Oceanogr., $12: 685-695$.

EPPLEY, R. W. \& THOMAS, W, H. 1969. Comparison of half-saturation constants for growth and nitrate uptake of marine phytoplankton. J. Phycol., 5(4):375-379

FAIRCHILD, E. \& SHERIDAN, R. P. 1974. A physiological investigation of the hot spring diatom, Achnanthes exigua Grün. J. Phyco1., 10:1-4.

GUILLARD, R. R. L. \& RYTHER, J. H. 1962. Studies of marine planktonic diatoms. I. Cyclotella nana (Hustedt) and Detonula confervacea (Cleve). Gram. Can. J. Microbiol., 8:229-239.
MacISAAC, J. J. \& DUGDALE, R. C. 1969. The kinetics of nitrate and ammonia uptake by natural population of marine phytoplankton. Deep-sea Res., $16: 45-57$.

MEEKS, J. C. 1974. Chlorophy11s. In: Stewart, W. D. P., ed. - Algal physiology and biochemistry. London.

MORRIS, I.; GLOVER, H. E. \& YENTSCH, C. S. 1974. Products of photosynthesis by marine phytoplankton: the effect of environmental factors on the relative rates of protein synthesis. Mar. Biol., 27:1-9.

MULLIN, J. B. \& RILEY, J. P. 1955. The spectrophotometric determination of nitrate in natural waters, with particular reference to sea-water. Analytica chem. Acta, 12:64-90.

PAASCHE, E. 1968. Marine plankton algae with light-dark cycles. II. Ditylum brigthwellii and Nitzschia turgidula. Physiologia P1., 21:6677 .

SCHMIDT, G. 1982. Algumas observações sobre a cinética do fitoplâncton marinho. 1. Influência da concentração de nitrato e amônia na velocidade de crescimento e de assimilação desses nutrientes na diatomácea Phaeodactylum tricornutum (Bohlin). Bolm Inst. oceanogr., S Paulo, 31(2):13-27.

SOURNIA, A. 1974. Circadian periodicities in natural populations of marine phytoplankton. Adv. mar. Biol., 12: 325-389.

STRICKLAND, J. D. H. \& PARSONS, T. R. 1968. A practical handbook of seawater analysis. Bull. Fish. Res. Bd Can., (167):1-311.

TEIXEIRA, C. \& VIEIRA, A. A. H. 1976. Nutrient experiment using Phaeodactylum tricornutum as an assay organism. Bolm Inst. oceanogr., S Paulo, 25:29-42. 
THOMAS, H. W. 1970. Effect of ammonium and nitrate concentration on chlorophyl1 increases in natural tropical Pacific phytoplankton populations. Limnol. Oceanogr., $15: 386-394$.

\& DODSON, A. N. 1974.

Effect of interactions between temperature and nitrate supply on the ce11-division rates of two marine phytoflagellates. Mar. Bio1., 24:213-217.
VIEIRA, A. A. H. 1975. Estudos experimentais em fitoplâncton marinho. Dissertação de mestrado. Universidade de São Paulo, Instituto Oceanogrāfico, 115p.
(Received 10-Dec-1983; accepted 16-May-1983) 